\title{
TROPHIC AND TEMPORAL NICHE INTERACTIONS IN \\ SYMPATRIC POPULATIONS OF EREMOBATES \\ PALPISETULOSUS FICHTER AND E. MORMONUS (ROEWER)
}

(SOLPUGIDA: EREMOBATIDAE)

\author{
FRED PUnZo \\ Department of Biology, Box $5 \mathrm{~F}$ \\ University of Tampa \\ Tampa, FL 33606, USA
}

\begin{abstract}
Studies were conducted from April to August 1993, on the diets and dietary overlap, as well as diel activity patterns of sympatric populations of the solpugids, Eremobates palpisetulosus and E. mormonus. Although both species are generalist predators, they do exhibit different prey preferences based on the hardness of the cuticle. Seventy eight percent of the diet of E. palpisetulosus consisted of hard-bodied orthopteran and coleopteran insects, whereas 77\% of the diet of E. mormonus consisted of softer-bodied dipteran, heteropteran, and orthopteran insects as well as spiders. No significant dietary differences were found between sexes. Both solpugid species exhibit similar temporal patterns of activity although $E$. mormonus does remain active at the surface for a longer period of time.
\end{abstract}

\section{INTRODUCTION}

The importance of competition as a primary factor in determining the structural organization of animal communities has been the subject of intensive debate over the last two decades (Schoener, 1974; Connor and Simberloff, 1979; Dunham, 1980; Roughgarden, 1986; Punzo, 1992). It has also been suggested that various multidimensional niche axes (i.e. temperature, food, space, time) can have significant effects on other ecological interactions including competition (Tracy and Christian, 1986). Arthropod predators that

Manuscript received 17 May 1994. 
inhabit xeric regions frequently exhibit similar temporal patterns of activity (nocturnal) and often feed on similar prey items (Cloudsley-Thompson, 1975; Punzo, 1994a, 1994b). In view of the aridity, high temperatures, and fluctuating prey density levels that often characterize desert ecosystems, the potential for intra- and interspecific competition is quite high (Dunham, 1980).

Solpugids are a major component of the arachnid fauna inhabiting desert regions (Muma, 1951; Cloudsley-Thompson, 1977; Punzo, 1993, 1994c). Although some information is available on the hunting behavior (Bolwig, 1952; Cloudlsey-Thompson, 1961; Muma, 1966; Wharton, 1987), diet (Punzo, 1994b, 1994c, 1994d) and thermal requirements (Cloudsley-Thompson, 1977; Punzo, 1994a) of Solpugida, no studies have been conducted on the possible competitive interactions between sympatric species. The purpose of the present study was to analyze the dietary preferences and temporal patterns of activity for the solpugids, Eremobates palipsetulosus and E. mormonus.

\section{MATERIALS AND METHODS}

Using total body length as an indicator (Muma, 1951), adult males (18-23 mm, total body length) and females (19-26 mm) of E. palpisetulosus and E. mormonus were collected and marked as previously described by Punzo (1994a), as they wandered on the surface of the ground at night during April-August, 1993. All animals were collected within a $10 \mathrm{~km}$ radius of Lajetas (Brewster Co., Texas), located within the northern region of the Chihuahuan Desert. A detailed description of the vegetational zones and geology of this region of Trans Pecos Texas is given by Tinkam (1948). Individuals of both species were collected on sandy substrates associated with a sotol-lechuguilla community, with the dominant vegetation consisting of sotol (Dasylirion leiophyllum) creosote (Larrea divaricata), tarbrush (Flourensia cernua), mesa sacahuista (Nolina erumpens), lechuguilla (Agave lecheguilla), mesquite (Prosopis glandulosa) and scattered clumps of chino grass (Bouteloua breviseta). Collection methods included hand-collecting and the use of pitfall traps.

Solpugids were identified following Muma (1951). Data on the time of day, place of capture (utilizing USGS topographical maps), total body length, sex, surface temperatures, and the presence of 
prey in the chelicerae were recorded for each animal as previously described by Punzo $(1991,1992)$. A total of 463 E. palpisetulosus adults were collected, 64 of which $(13.8 \%)$ were in possession of a prey item, as well as 387 E. mormonus adults, 47 of which (12.1 $\%)$ had a prey item. Prey items were carefully removed from the chelicerae using forceps and placed in $70 \%$ ethanol for subsequent identification to order or family depending on the degree of digestion. Levins' standardized measure of trophic niche breadth $\left(\mathrm{B}_{\mathrm{A}}\right)$ was calculated from data based on percent frequency of occurrence of food items as described by Krebs (1989), where $B_{A}$ values can range from 0 (prey species in only one prey category) to 1.0 (prey species represented equally in all resource categories). Dietary and temporal niche overlap (D) were calculated according to Floyd and Jenssen (1983):

$$
\mathrm{D}=1-0.5 \sum_{\mathrm{i}=1}^{\mathrm{n}} \mathrm{P}_{\mathrm{xi}}-\mathrm{P}_{\mathrm{yi}}
$$

where $\mathrm{P}_{\mathrm{xi}}$ and $\mathrm{P}_{\mathrm{yi}}$ are frequencies of prey classes or time intervals for species $\mathrm{x}$ and $\mathrm{y}$, respectively, for the $\mathrm{i}^{\text {th }}$ category. The index, $\mathrm{D}$, can range from 0 (no overlap) to 1.0 (complete overlap). Frequencies $(\%)$ of occurrence for various prey taxa (trophic niche) and time intervals of ground surface activity (temporal niche) were used for the determination of $D$ as described by Floyd and Jenssen (1983) and Schoener (1983). All statistical procedures used in data analyses followed Sokal and Rohlf (1981).

\section{RESULTS AND Discussion}

E. palipsetulosus and E. mormonus are both generalist predators and will feed on a wide variety of arthropod prey species (Table 1). This is in general agreement with previous data on allopatric populations of E. palpisetulosus (Punzo, 1994b) and E. mormonus (Punzo, 1994c) from different study sites, as well as for several other solpugid species (Muma, 1966; Punzo, 1994d). Diets of males and females appear to be similar (ANOVA, p > 0.5). E. remobates palpisetulosus feeds more extensively on hard-bodied arthropods such as coleopterans and orthopterans, whereas $E$. mormonus captured a higher proportion of soft-bodied prey such as blattellid and gryllid nymphs as well as spiders. This is reflected 
Table 1 . Number of prey items captured by Eremobates palpisetulosus $(\mathrm{N}=64$ solpugids and prey items) and E. mormonus $(\mathrm{N}=47)$ during field observations. Percentage (frequency of occurrence) of total prey given in parentheses. Development stage of prey: A (adult), N (nymph), L (larva).

\begin{tabular}{|c|c|c|}
\hline Prey taxon & E. palpisetulosus & E. mormonus \\
\hline \multicolumn{3}{|l|}{ Insecta } \\
\hline Coleoptera & $(26.5)$ & (4.3) \\
\hline Carabidae (A) & 8 & \\
\hline Scarabaeidae (A) & 3 & \\
\hline Tenebrionidae (A) & 1 & 2 \\
\hline Undetermined (A) & 5 & \\
\hline Dictyoptera & (1.5). & (14.9) \\
\hline Blattellidae (N) & 1 & 7 \\
\hline Diptera & $(1.5)$ & $(8.5)$ \\
\hline Muscidae (A) & & 1 \\
\hline Undetermined (A) & 1 & 3 \\
\hline Heteroptera & (1.5) & $(8.5)$ \\
\hline Lygaeidae (A) & 1 & \\
\hline Undetermined (A) & & 4 \\
\hline Lepidoptera & (3.1) & $(4.2)$ \\
\hline Noctuidae (A) & 1 & \\
\hline Nymphalidae (A) & 1 & 2 \\
\hline Orthoptera & $(51.6)$ & $(29.8)$ \\
\hline Acrididae (A) & 21 & \\
\hline$(\mathrm{N})$ & 1 & 3 \\
\hline Gryllidae (A) & 1 & 11 \\
\hline Undetermined (A) & 7 & \\
\hline (N) & 3 & \\
\hline Arachnida & $(14.1)$ & $(29.8)$ \\
\hline Araneae (A) & 5 & 14 \\
\hline Scorpiones (A) & 4 & \\
\hline
\end{tabular}

in the relatively low degree of dietary overlap $(D=0.56)$. Several nocturnal arthropod species such as velvet ants (Mutillidae), blister beetles (Meloidae), and millipedes, characterized by well known chemical defense mechanisms and common in the study area, were not captured by either of these solpugid species. Measurements of trophic niche breadth (Table 2) indicate that E. palpisetulosus chooses prey from a narrower resource range than $E$. mormonus. No evidence of cannibalism was found although it has been reported for other solpugids (Bolwig, 1952; Muma, 1966). 
Table 2. Levins' standardized measure of trophic niche breadth $\left(B_{A}\right)$ based on the percent frequency of occurrence of various prey items.

\begin{tabular}{lcc}
\hline & \multicolumn{2}{c}{ Percent frequency of occurrence } \\
Prey taxon & E. palpisetulosus & E. mormonus \\
\hline Coleoptera & 26.5 & 4.3 \\
Dictyoptera & 1.5 & 14.9 \\
Diptera & 1.5 & 8.5 \\
Heteroptera & 1.5 & 8.5 \\
Lepidoptera & 3.1 & 4.2 \\
Orthoptera & 51.6 & 29.8 \\
Arachnida & 14.1 & 29.8 \\
\multicolumn{1}{c}{$\mathrm{B}_{\mathrm{A}}$} & 0.298 & 0.598 \\
\hline
\end{tabular}

Both solpugid species exhibit strong nocturnal patterns of activity (Table 3) which is common for desert arachnids (CloudsleyThompson, 1977; Wharton, 1987; Punzo, 1991, 1994a). No individuals of either species were observed on the surface before $2100 \mathrm{hr}$ in the summer and before $2000 \mathrm{hr}$ in the spring. The peak period of activity for E. palpisetulosus was between 2200 and $2400 \mathrm{hr}$ in the spring, and between 2200 and $0100 \mathrm{hr}$ in the summer. For E. mormonus, peak activity periods were between 2200 and $0100 \mathrm{hr}$ for both spring and summer months. Calculation of temporal niche overlap (D) yielded a value of 0.67 for the spring and 0.64 for the summer, indicating that these solpugids occupy a similar temporal niche axis.

This study indicates that although these solpugids are generalist predators, they appear to select different types of prey perhaps based on the hardness of the exoskeleton. This may represent one way in which interspecific competition is reduced in these sympatric species. With respect to temporal patterns of activity, $E$. mormonus adults exhibited a longer period of activity at the surface. Since microhabitat, food and time represent the three major categories of resource dimensions (Schoener, 1974; Roughgarden, 1986), a difference in any one of these dimensions could effectively reduce competition. Future studies should focus on possible species differences in foraging (hunting behavior, prey prepara- 


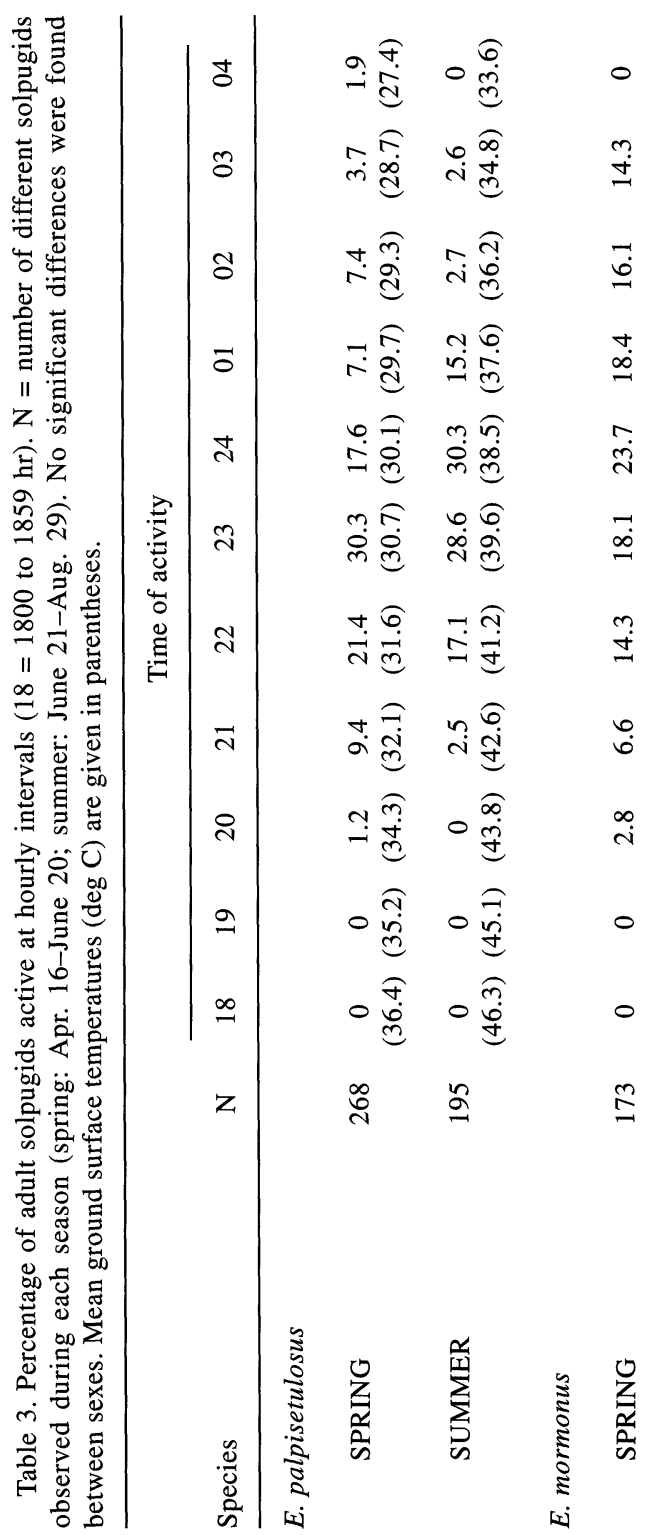


tion), microhabitat preference, the role of soil hardness in habitat selection (especially burrowing sites), fecundity, age and body size of the female at first reproduction, mating behavior, longevity, and responses to themal stress.

\section{ACKNOWLEDGEMENTS}

I thank James Botrell and my son, Thomas Punzo, for assistance in the collection of solpugids, and Brian Garman, Dept. of Mathematics (University of Tampa), for consultation on statistical analyses. I also thank the University of Tampa for a Faculty Development Grant which provided funds for travel and supplies, and the comments of anonymous reviewers on an earlier draft of the manuscript.

\section{REFERENCES}

Bolwig, N. 1952. Observations on the behavior and mode of orientation of hunting Solifugae. J. Ent. Soc. S. Afr. 15:239-240.

Cloudsley-Thompson, J. L. 1961. Some aspects of the physiology and behavior of Galeodes arabs. Ent. exp. appl. 4:257-263.

Cloudsley-Thompson, J. L. 1975. Adaptations of Arthropoda to arid environments. Annu. Rev. Ent. 20:261-283.

Cloudsley-Thompson, J. L. 1977. Adaptational biology of Solifugae (Solpugida). Bull. Br. arachnol. Soc. 4:61-71.

Conner, E. F. and D. Simberloff. 1979. The assembly of species communities: chance or competition? Ecology 60:1132-1140.

Dunham, A. E. 1980. An experimental study of competition between iguanid lizards Sceloporus merriami and Urosaurus ornatus. Ecol. Monogr. 50:309-330.

Floyd, H. B. and T. A. Jenssen. 1983. Food habits of Jamaican lizard Anolis opalinus: resource partitioning and seasonal effects examined. Copeia 1983:319-331.

Krebs, C. J. 1989. Ecological Methodology. Harper and Row, Publ., New York. 654 pp.

Muma, M. H. 1951.The arachnid order Solpugida in the United States. Bull. Am. Mus. Nat. Hist. 97:34-141.

Muma, M. H. 1966. Feeding behavior of North American Solpugida. Fla. Entomol. 50:199-216.

Punzo, F. 1991. Intraspecific variation to thermal stress in the tarantula, Dugesiella echina Chamberlin (Orthognatha, Theraphosidae). Bull. Br. Arachnol. Soc. $8: 277-283$.

Punzo, F. 1992. Dietary overlap and activity patterns in sympatric populations of Scaphiopus holbrooki (Pelobatidae) and Bufo terrestris (Bufonidae). Fla. Scient. 55:38-44.

Punzo, F. 1993. An analysis of the free amino acids, neurotransmitters and enzymes in the nervous system of Solpugida (Arachnida). Comp. Biochem. Physiol. 106C:699-703.

Punzo, F. 1994a. Diet and feeding behavior of the solpugid, Eremobates palpisetulosus (Solpugida : Eremobatidae). Psyche 100:151-162. 
Punzo, F. 1994b. Intraspecific variation in response to temperature amd moisture in Eremobates palpisetulosus Fichter (Solpugida, Eremobatidae) along an altitudinal gradient. Bull. Br. Arachnol. Soc. (in press).

Punzo, F. 1994c. An analysis of feeding and optimal foraging behavior in the solpugid Eremobates mormonus (Roewer) (Solpugida, Eremobatidae). Bull. Br. Arachnol. Soc. (in press).

Punzo, F. 1994d. Feeding and prey preparation in the solpugid, Eremorhax magnus (Solpugida: Eremobatidae). Pan Pacific Entomol. (in press).

Punzo, F. and G. Huff. 1989. Comparative temperature and water relations and the effects of thermal acclimation on Tenebrio molitor and Tenebrio obscurus (Coleoptera: Tenebrionidae). Comp. Biochem. Physiol. 93A:527-533.

Punzo, F. and J. Mutchmor. 1980. Effects of temperature, relative humidity and period of exposure on the survival capacity of Tenebrio molitor (Coleoptera: Tenebrionidae). J. Kansas Entomol. Soc. 53:260-270.

Roughgarden, J. 1986. A comparison of food - limited and space - limited animal competition communities. In: Community Ecology (Diamond, J. and T.J. Case, eds.), pp. 492-516, Harper and Row, New York.

Schoener, T. W. 1974. Resource partitioning in ecological communities. Science 185:27-39.

Schoener, T. W. 1983. Field experiments on interspecific competition. Am. Nat. 12:240-285.

Sokal, R. R. and F. J. Rohlf. 1981. Biometry. 2nd ed., W. H. Freeman and Company, New York. 859 pp.

Tinkam, E. R. 1948. Faunistic and ecological studies on the Orthoptera of the Big Bend Region of Trans Pecos Texas. Am. Midl. Nat. 40:521-563.

Tracy, C. R. and K. A. Christian. 1986. Ecological relations among space, time and thermal niche axes. Ecology 67:609-615.

Wharton, R. A. 1987. Biology of the diurnal Metasolpuga picta (Kraepelin) (Solifugae, Solipugidae) compared with nocturnal species. J. Arachnol. 14:363-383. 

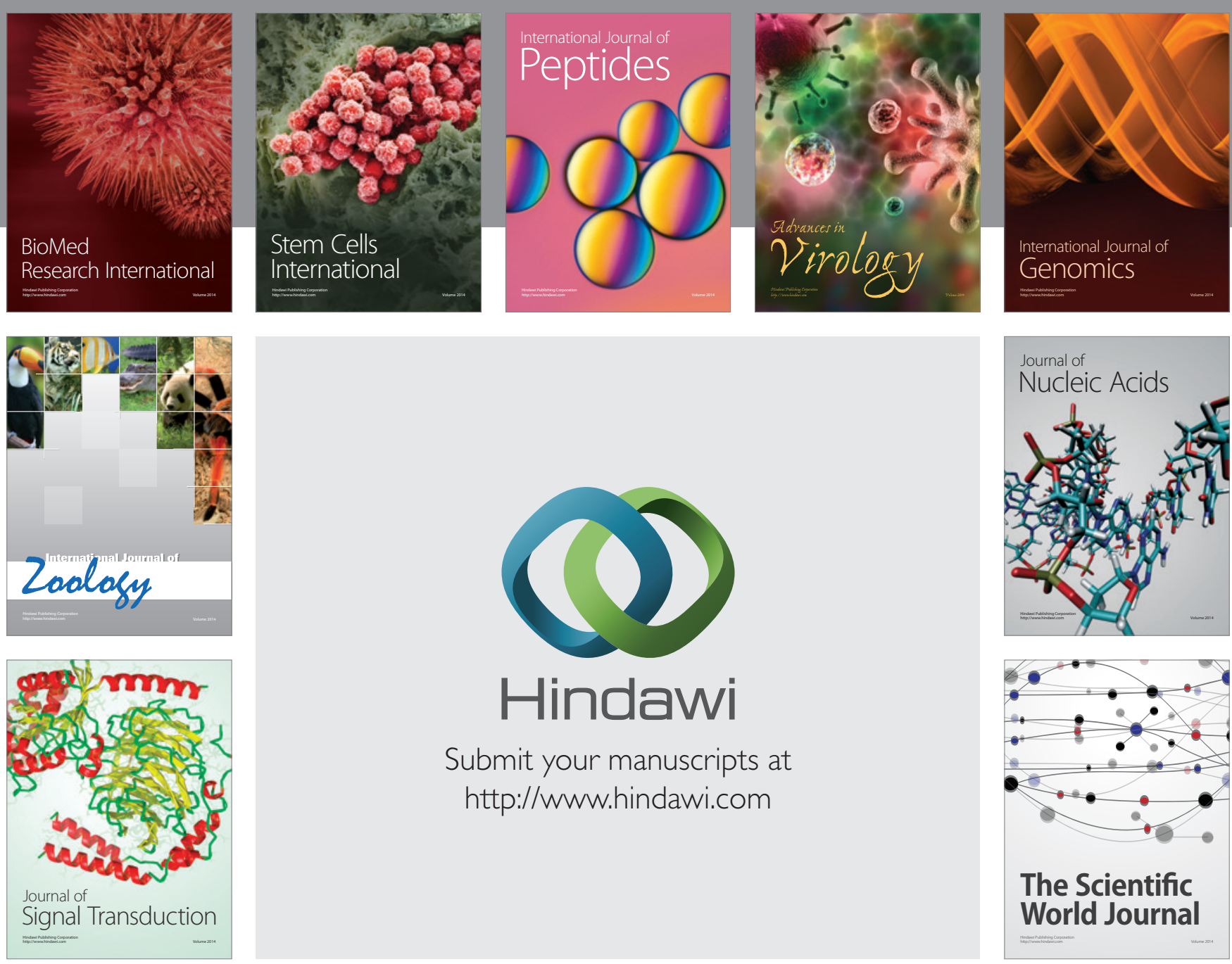

Submit your manuscripts at

http://www.hindawi.com
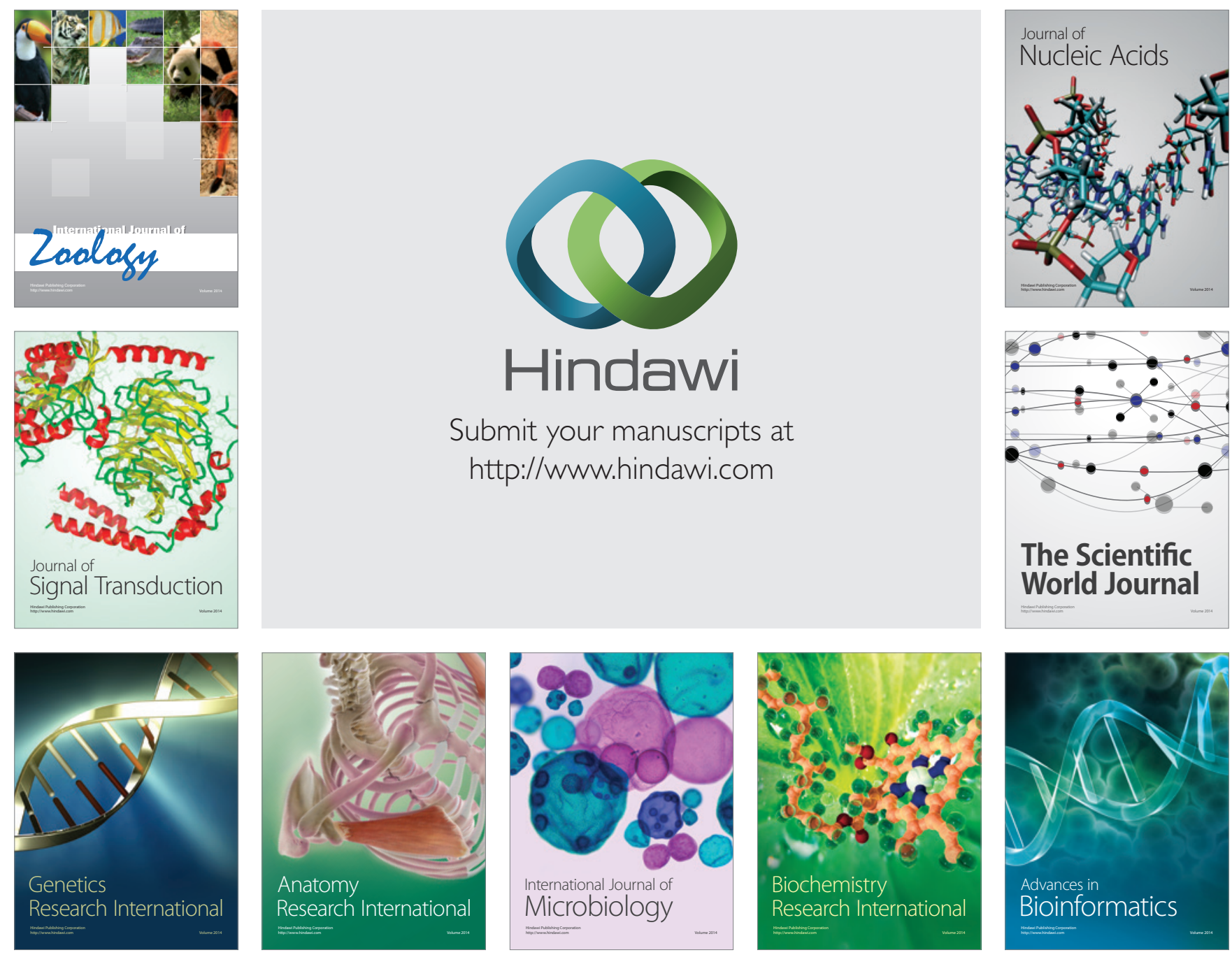

The Scientific World Journal
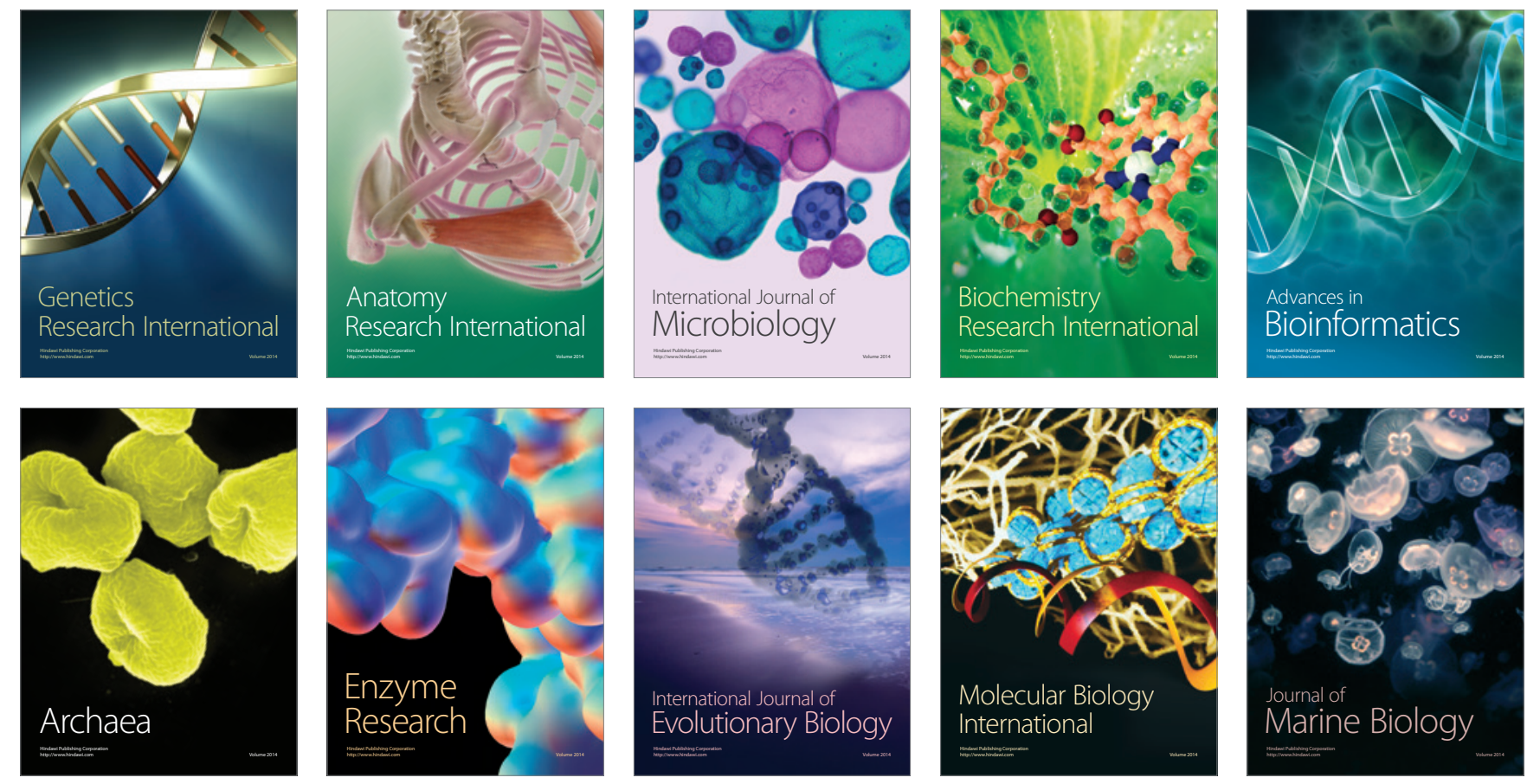